\title{
Migration and Accumulation of Heavy Metals in a Chicken Manure-Compost-Soil-Apple System
}

\author{
Xin Yu ${ }^{1,2}$, Guozhong Chen ${ }^{1,3 *}$, Xingxiao Zhang, ${ }^{1,3 * *}$, Jianlong Zhang ${ }^{1,3}$, Linlin Jiang ${ }^{1,3}$, \\ Hongwei Zhu ${ }^{1,3}$, Zhibin Feng ${ }^{1,3}$, Youzhi Li ${ }^{2}$, Tao Feng ${ }^{2}$, Xiang Zhang ${ }^{4}$ \\ ${ }^{1}$ School of Life Sciences, Ludong University, Yantai, China \\ ${ }^{2}$ Shandong Provincial Key Laboratory of Quality Safty Monitoring and Risk Assessment for Animal Products, \\ Ji'nan, China \\ ${ }^{3}$ Yantai Key Laboratory of Animal Pathogenetic Microbiology and Immunology, Yantai, China \\ ${ }^{4}$ Institute of Agro-Food Science and Technology, Shandong Academy of Agricultural Sciences, Ji'nan, China
}

Received: 27 April 2020

Accepted: 7 December 2020

\begin{abstract}
This study investigated the contents and speciation of the heavy metals $\mathrm{As}, \mathrm{Cd}, \mathrm{Hg}, \mathrm{Cr}, \mathrm{Pb}, \mathrm{Cu}$, and $\mathrm{Zn}$ in a chicken manure-compost-soil-apple system. As, $\mathrm{Cd}$, and $\mathrm{Hg}$ concentrations in chicken manure samples exceeded the National Agricultural Standard for Organic Fertilizers of China. Moreover, the composting process further increased heavy metal concentrations in the chicken manure. However, the composting process also changed the speciation of the heavy metals. In orchard soils that used chicken fertilizer compost for long periods, $\mathrm{Cd}$ and $\mathrm{Hg}$ concentrations exceeded the required limits for orchards stipulated by the Environmental Quality Standard for Soils of China. As, Cd, and $\mathrm{Hg}$ heavy metal concentrations in the apple fruit also exceeded food pollutant limits specified by the National Food Safety Standard, especially for $\mathrm{Hg}$, which was 25 times above the allowable limit. As, Cd, and $\mathrm{Hg}$ concentrations in chicken manure, compost, soil, and apple fruit all exceeded standard levels (except for As in soil), while the remaining heavy metals $(\mathrm{Cr}, \mathrm{Pb}, \mathrm{Cu}$, and $\mathrm{Zn}$ ) were below the standard. This implies a correlation between the migration and accumulation of heavy metals in the chicken manure-compost-soil-apple system.
\end{abstract}

Keywords: heavy metals, chicken manure, compost, soil, apple

\section{Introduction}

China is a large agricultural country; in 2016, it produced a total of 3.8 billion tons of livestock and poultry manure. To promote sustainable agricultural development, on 12 June 2017 the General Office

*e-mail: 215671442@qq.com

**e-mail: zhangxingxiao2018@163.com of the State Council issued goals to accelerate the recycling of livestock and poultry waste. This will result in more livestock and poultry manure being treated for use on fruit and vegetable farmland. Many studies have shown that livestock and poultry manure contains large amounts of heavy metal pollutants [1] and, if used as a fertilizer, may contaminate farmland soil [2] and accumulate in grain, fruits, and vegetables [3], ultimately negatively impacting human health [4]. 
Heavy metal pollution is not only related to pollutant concentrations, but also to their speciation, migration, and bioavailability characteristics. According to the Tessier speciation scheme [5], heavy metals can be divided into exchangeable fractions, carbonate bound fractions, Fe-Mn oxide bound fractions, organically bound fractions, and residual fractions. Exchangeable heavy metal fractions are sensitive to environmental change, susceptible to migration and transformation, and can be absorbed by plants [6]. Carbonate bound heavy metal fractions are related to the $\mathrm{pH}$ of the soil. An increase in soil $\mathrm{pH}$ will result in carbonate co-precipitation. When soil $\mathrm{pH}$ decreases, the heavy metals are released again into the environment. This type of heavy metal can also be utilized by living organisms [7]. Fe-Mn oxide bound fractions are generally not easily utilized [8]. Organically bound fractions can be dissolved under certain conditions and may affect the environment [9]. Residual heavy metal fractions are generally stable in nature; they can remain in the soil in a passive state for long periods of time and are not easily absorbed by plants [10].

Therefore, in recent years, some researchers have attempted to change the forms of heavy metals in the environment using treatment methods that transform them from bioavailable to bio-unavailable forms. Dong et al. [11] reported that high solid anaerobic digestion increased the bioavailability of $\mathrm{Cu}, \mathrm{Zn}, \mathrm{Ni}$, and $\mathrm{Cr}$, while decreasing the bioavailability of $\mathrm{Pb}$. Lv et al. [12] found that vermicomposting decreased the mobility and bioavailability of heavy metals, and increased the relative content of bio-unavailable heavy metal forms. Liu et al. [13] showed that composting can reduce $70 \%$ of exchangeable $\mathrm{Cd}$, and immobilize $\mathrm{Cd}$ in soil; thus, composting can be used for remediation of Cd-contaminated soils.

China is one of the biggest apple producing countries in the world, where apple orchards cover an area of 23,292 million $\mathrm{m}^{2}$. At a rate of $3 \mathrm{~kg}$ of fertilizer per $\mathrm{m}^{2}$ per year, 69.84 million tons of organic fertilizer are required each year. Additionally, at a rate of 0.3-0.6 tons of organic fertilizer per ton of livestock and poultry manure, approximately 116.4-232.8 million tons of manure are used. Therefore, heavy metal contamination of orchard soil and fruit is a problem deserving of significant attention. Wang et al. [14] studied the heavy metal content of soil and fruit from 48 apple orchards located in the Liaodong Peninsula. They found that $\mathrm{Cr}$ and $\mathrm{Cu}$ concentrations in some soil samples exceeded the allowable limits for heavy metal contents in orchard soils in China, and $\mathrm{Cr}, \mathrm{Cd}$, and $\mathrm{Zn}$ concentrations in some fruit samples exceeded the Chinese agricultural product safety requirements for pollution-free fruit. These results were attributed to the natural physicochemical properties of the soil $[15,16]$. Wang et al. [17] reported that long-term use of $\mathrm{Cu}$-based pesticides causes the $\mathrm{Cu}$ content in apple orchard soils to increase each year, indicating that pesticide and fertilizer use affects heavy metal contents in the soil. In this study, the content and forms of heavy metals found in chicken manure, compost, apple orchard soil, and fruit were studied in order to clarify the migration and accumulation patterns of heavy metal contaminants within the livestock manure-compostsoil-fruit system.

\section{Material and Methods}

\section{Sampling}

The experiments in this study involved an apple orchard in Shandong Province, China. There are 11 broiler chicken farms located in the vicinity of the apple orchard (breeding scale of 20,000-100,000). The resulting chicken manure is consolidated and transported to a nearby organic fertilizer plant where it is mixed with rice husk powder to a $\mathrm{C}: \mathrm{N}$ ratio of 25. Next, $1 \%$ calcium superphosphate is added, and a dose of fermentation bacteria is introduced. The water content is adjusted to approximately $50 \%-60 \%$, and after being fully mixed, the mixture is placed into solid-state fermentation tanks. After 24 hours of forced-ventilation fermentation, the resulting material is stockpiled into $1-1.5 \mathrm{~m}$ high and $4-5 \mathrm{~m}$ wide heaps that continue to decompose. The heaps are turned over once every day and, after 21 days, the fermentation process is completed. The heaps are sun-dried until the water content reaches $30 \%-35 \%$ and then stored. Every October, chicken manure compost is applied to the orchard at a rate of $3 \mathrm{~kg} / \mathrm{m}^{2}$, using a combination of trenching and sprinkling. Trenching application involved digging a $40-\mathrm{cm}$ wide and $50-\mathrm{cm}$ deep trench between the fruit tree rows, and filling the bottom $10 \mathrm{~cm}$ of the trench with straw and weeds. Next, a mix of the manure compost and soil was applied and the trench was filled with soil. The sprinkling application method involved spreading the manure compost directly under the trees and turning over the soil. Sampling was performed during September 2016. The chicken manure samples were taken from the breeding farms, the manure compost samples were taken from the organic fertilizer plant, and the soil and apple fruit samples were taken from the apple orchards. A Dutch shovel was used for the variable-depth soil samples. At each depth $(0-10 \mathrm{~cm}, 10-20 \mathrm{~cm}, 20-30 \mathrm{~cm}, 30-40 \mathrm{~cm})$, five random sampling sites were selected and $200 \mathrm{~g}$ of soil for each sampling site was mixed evenly, dried naturally, ground to pass through a 1-mm sieve, and stored at $4^{\circ} \mathrm{C}$. The apple fruit sample surfaces were thoroughly washed, peeled, cored, homogenized, and stored at $4^{\circ} \mathrm{C}$.

\section{Detection and Analysis}

The total extraction method involved weighing $1-5 \mathrm{~g}$ samples (to a precision of $0.001 \mathrm{~g}$ ) and placing 
them in a $100-\mathrm{mL}$ beaker. Next, $20 \mathrm{~mL}$ of aqua regia $\left(\mathrm{HCl}: \mathrm{HNO}_{3}=3: 1\right)$ was added, and the beaker was covered with a watch glass. Next, the contents were micro-boiled on a heating plate at a temperature of $150^{\circ} \mathrm{C}-200^{\circ} \mathrm{C}$ for 30 minutes. When the contents were almost dry, the beaker was removed from the heat. The watch glass and the inner wall of the beaker were then rinsed with a small amount of water. After cooling, $2 \mathrm{~mL}$ of $50 \%$ hydrochloric acid solution was added and heated until dissolved, then cooled and filtered. The filtrate was collected into a $50-\mathrm{mL}$ graduated flask. After the filtrate had dried, it was rinsed more than three times using a small amount of ultra-pure water. The filtrates were then combined, and ultra-pure water was added to $50 \mathrm{~mL}$ and mixed thoroughly before measurement.

The Tessier continuous extraction method was used for heavy metal speciation analysis [5]. The following fractions were obtained: exchangeable, carbonate bound, Fe-Mn oxide bound, organically bound, and residual. An ICPE-9000 spectrometer (Shimadzu, Japan) and inductively coupled plasma optical emission spectrometry analysis (ICP-OES) were used. The heavy metal standard was supplied by the National Standard Material Center of the Beijing Wanjia Shouhua Biotechnology Co., Ltd.

\section{Statistical Analysis}

The experimental data were expressed using the mean values of three parallel sets of data. Standard deviations were also calculated. Origin 9.0 was used for mapping, and SPSS (19.0) was used for the statistical analysis. ANOVA (analysis of variance) and Tukey's range test were employed for the statistical analysis, with a significance level of $p<0.05$.

\section{Results and Discussion}

\section{Heavy Metal Content in Chicken Manure}

Table 1 shows the heavy metal content in chicken manure raw materials from large-scale commercial broiler farms. The order of mean heavy metal contents was found to be $\mathrm{Zn}>\mathrm{As}>\mathrm{Cu}>\mathrm{Cr}>\mathrm{Pb}>\mathrm{Hg}>\mathrm{Cd}$. The median values were essentially consistent with the mean values. Low standard deviation values reflect small variations in the heavy metal contents of various manure samples. This might be due to similarities in chicken coop design, breeding scale and technology, the proportion and quantity of feed, and other conditions at the various farms. The skewness coefficient, which is a measure of the asymmetry of the distribution relative to a normal distribution, confirms a normal distribution of heavy metals in the chicken manure. The kurtosis values were extremely low owing to the fact that most samples clustered around the central mean value.

These statistical properties show that the mean and median values correspond to the concentrations of the heavy metals. As, $\mathrm{Cd}$, and $\mathrm{Hg}$ contents in the chicken manure exceeded the limits for heavy metal contents of organic fertilizer products, as specified by the Organic Fertilizer Standard NY 525-2012. The main source of As in the chicken manure was found to be As-containing antibiotics used during the breeding process. Most of these antibiotics are not absorbed by the poultry, and are excreted through urine and feces [18]. The $\mathrm{Cd}$ and $\mathrm{Hg}$ contents in the chicken manure also exceed standard values because fishmeal, which is commonly added to chicken feed, is generally high in $\mathrm{Cd}$ and $\mathrm{Hg}$ [19]. No abnormal values were observed in box plots (Fig. 1), meaning that the heavy metal content of the chicken manure was not affected by external factors.

Table 1. Heavy metal contents $(\mathrm{mg} / \mathrm{kg}$ ) of chicken manure.

\begin{tabular}{|c|c|c|c|c|c|c|c|}
\hline & $\mathrm{As}$ & $\mathrm{Cd}$ & $\mathrm{Hg}$ & $\mathrm{Cr}$ & $\mathrm{Pb}$ & $\mathrm{Cu}$ & $\mathrm{Zn}$ \\
\hline Mean & 74.46 & 4.30 & 14.93 & 17.85 & 15.23 & 45.33 & 152.50 \\
\hline Standard deviation & 13.22 & 1.37 & 2.82 & 5.01 & 7.53 & 5.56 & 22.47 \\
\hline Q1 & 62.19 & 3.84 & 12.93 & 13.64 & 10.85 & 41.91 & 145.61 \\
\hline Median & 71.46 & 4.25 & 13.70 & 17.24 & 11.57 & 45.21 & 155.07 \\
\hline Q3 & 85.83 & 5.28 & 16.62 & 22.53 & 18.67 & 48.35 & 163.08 \\
\hline Minimum & 56.34 & 1.52 & 11.71 & 12.11 & 7.46 & 36.83 & 107.20 \\
\hline Maximum & 93.57 & 6.03 & 20.44 & 26.08 & 27.90 & 55.83 & 183.75 \\
\hline Skewness & 0.12 & -0.92 & 0.81 & 0.39 & 1.08 & 0.24 & -0.75 \\
\hline Kurtosis & -1.59 & 0.35 & -0.25 & -1.48 & -0.66 & -0.05 & 0.54 \\
\hline NY 525-2012 & $\leq 15$ & $\leq 3$ & $\leq 2$ & $\leq 150$ & $\leq 50$ & - & - \\
\hline
\end{tabular}

a Organic fertilizer; Chinese agricultural industry standard (NY 525-2012). 


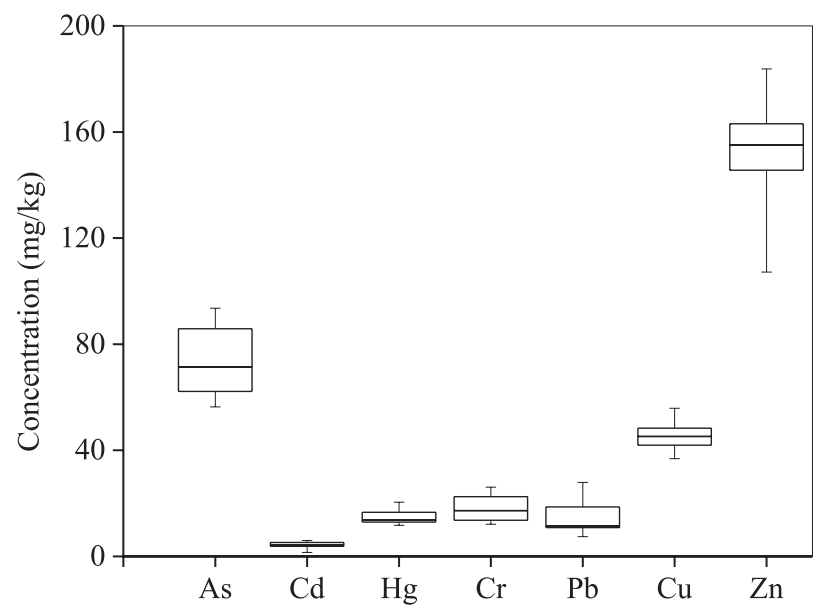

Fig. 1. Box-and-whisker plots of heavy metal concentrations in chicken manure. (Note the absence of outliers.)

\section{Effects of Composting on Heavy Metal Content and Speciation}

Fig. 2 compares the heavy metal contents in chicken manure before and after composting. The heavy metal contents increase after composting, within the significance level $(p<0.05)$, mainly due to the reduction in volume and weight caused by decomposition of the organic matter $[12,20,21]$. In addition to the change in the total content of heavy metals, significant variations in heavy metal speciation also occurred (Fig. 3). The most significant and important changes occurred in the exchangeable fractions of $\mathrm{As}, \mathrm{Cd}$, and $\mathrm{Hg}$, which decreased from $44.58 \%, 16.65 \%$, and $14.62 \%$ before composting to $35.25 \%, 1.82 \%$, and $3.18 \%$ after composting, respectively, and in the residual fractions of $\mathrm{As}, \mathrm{Cd}$, and $\mathrm{Hg}$, which increased from $0.68 \%, 3.68 \%$, and $4.31 \%$ before composting to $14.62 \%, 23.02 \%$, and $20.76 \%$ after composting, respectively.

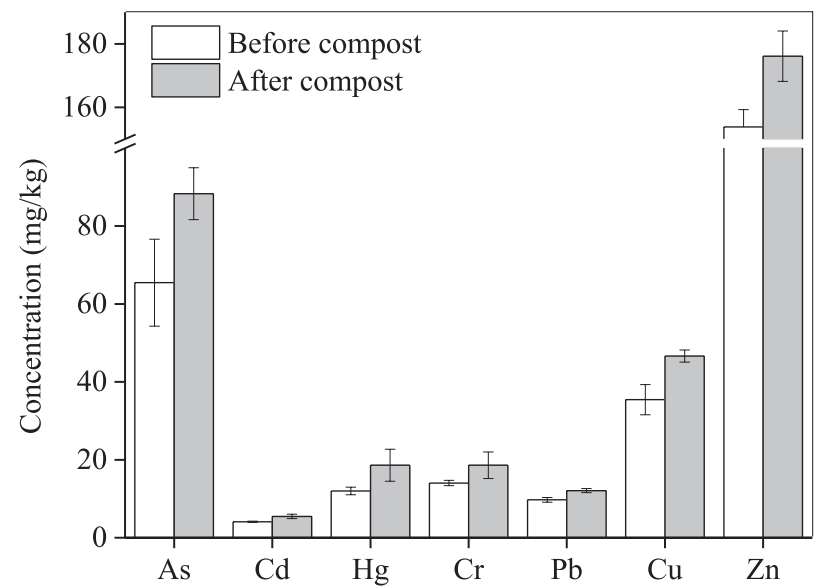

Fig. 2. Heavy metal contents in chicken manure before and after composting.

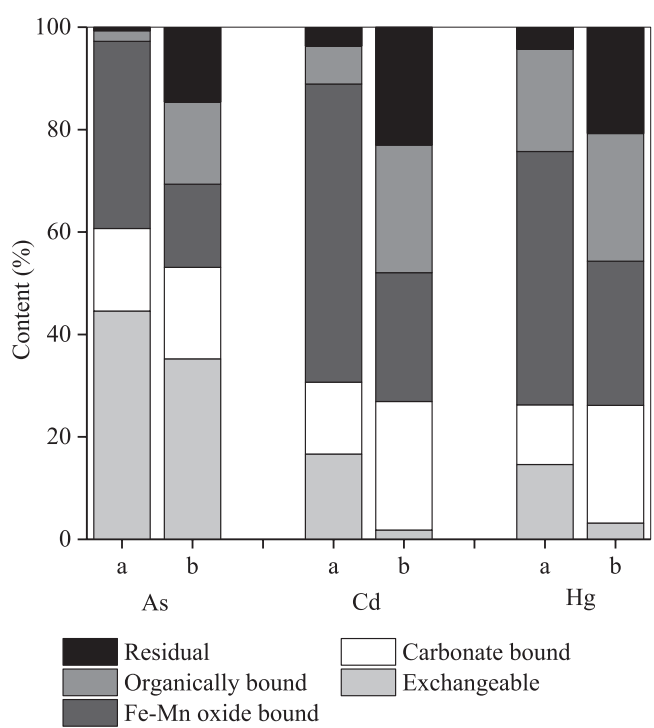

Fig. 3. As, $\mathrm{Cd}$, and $\mathrm{Hg}$ speciation a) before and b) after composting.

The reduction in highly reactive forms and the increase in stable forms of heavy metals indicate that the composting process has a significant effect on the passivation of heavy metals contained in chicken manure. The increase in the carbonate bound fractions of $\mathrm{As}, \mathrm{Cd}$, and $\mathrm{Hg}$ after composting related to the change in $\mathrm{pH}$ during composting. Fe-Mn oxide bound fractions are thermodynamically unstable under hypoxic conditions. Although the high-temperature composting process in this study mainly uses aerobic fermentation, it is impossible to avoid anaerobic fermentation. The Fe-Mn oxide bound fractions of As, $\mathrm{Cd}$ and $\mathrm{Hg}$ decreased from $36.52 \%, 68.22 \%$, and $49.45 \%$ to $16.23 \%, 25.16 \%$, and $28.14 \%$ after composting, respectively. Free heavy metal ions can react with and be bound by many types of organic matter. As a result, the organically bound fraction contents of $\mathrm{As}, \mathrm{Cd}$, and $\mathrm{Hg}$ increased from $2.11 \%$, $7.43 \%$, and $19.98 \%$ to $16.05 \%, 24.90 \%$, and $24.94 \%$, respectively, after composting. Studies on the increase of organically bound fractions of $\mathrm{Cd}$ due to composting have already been published [13]. Changes in As, Cd, and $\mathrm{Hg}$ speciation after composting indicates that the composting process can stabilize and immobilize heavy metals, and change their migration and bioavailability. Therefore, composting can reduce the relative amount of heavy metal absorption and accumulation in crops, reducing the risk of environmental pollution, as also shown by He et al. [22].

\section{Heavy Metal Contents and Speciation in Apple Orchard Soils}

The distribution of $\mathrm{As}, \mathrm{Cd}$, and $\mathrm{Hg}$ in the apple orchard soil cross-section was non-homogenous (Fig. 4), consistent with findings for $\mathrm{Cu}$ and $\mathrm{Zn}$ [23]. As and $\mathrm{Cd}$ concentrations were lower in the soil surface 
layer $(0-10 \mathrm{~cm})$ than in deeper layers $(10-40 \mathrm{~cm})$, possibly due to the fact that As and Cd dissolve and migrate downward after rain or irrigation. Moreover, $\mathrm{Hg}$ in the soil surface layer reached up to $16.81 \mathrm{mg} / \mathrm{kg}$, far exceeding the content of deeper layers. This might be because the surface layer is the most vulnerable to contamination by external $\mathrm{Hg}$, and organic matterrich soils display particularly strong adsorption and accumulation of $\mathrm{Hg}$ [24].

As, $\mathrm{Cd}$, and $\mathrm{Hg}$ speciation varies significantly at different soil depths (Fig. 5). The exchangeable and carbonate bound fractions of As in the surface layer $(0-10 \mathrm{~cm})$ were very high $(55.52 \%$ and $25.46 \%$, respectively), with a combined value of $80.97 \%$. The exchangeable and carbonate bound fractions of $\mathrm{Cd}$ and $\mathrm{Hg}$ were also very high $(12.02 \%$ and $76.02 \%$, and $15.75 \%$ and $60.50 \%$, respectively), totaling $88.04 \%$ and $76.25 \%$, respectively. The ratio of exchangeable and carbonate bound fractions to the total heavy metal content, which is known as the mobility factor or the activity coefficient, is used to assess the migration potential and bioavailability of heavy metals. Higher exchangeable and carbonate bound fraction contents indicate stronger migration potential and higher absorption and accumulation of heavy metals in crops $[25,26]$. The contents and speciation of heavy metal elements $\mathrm{As}, \mathrm{Cd}$, and $\mathrm{Hg}$ in the deeper soil layers $(10-40 \mathrm{~cm})$ were approximately equal, and their activity coefficients were $43.81 \%-52.96 \%, \quad 39.64 \%-43.30 \%$, and $37.31-39.24 \%$, respectively, lower than those in the surface layer. This indicates that heavy metals in deeper layers have lower mobility and bioavailability.

\section{Migration and Accumulation of Heavy Metals in the Soil-Apple Fruit Systems}

Table 2 shows the heavy metal contents of apple orchard soil and fruit. $\mathrm{Cd}$ and $\mathrm{Hg}$ concentrations in the apple orchard soil far exceeded the limits specified

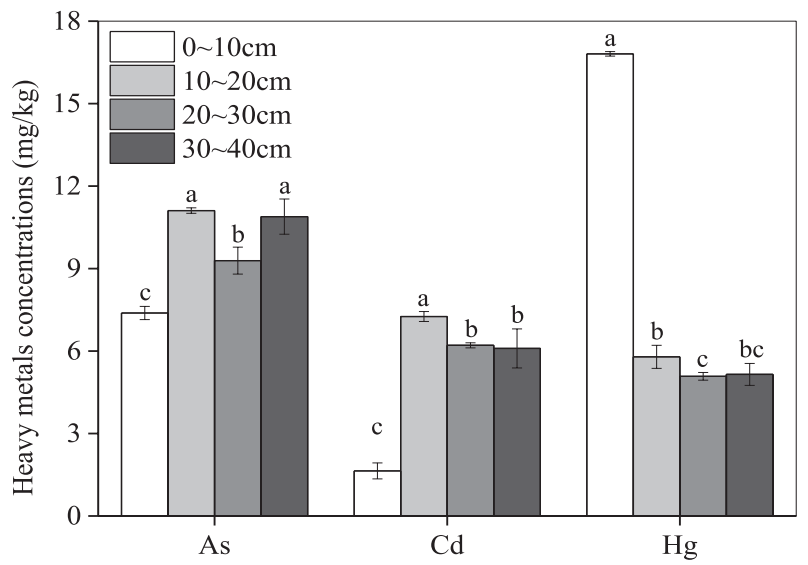

Fig. 4. As, $\mathrm{Cd}$, and $\mathrm{Hg}$ concentrations at various depths of apple orchard soil. Different letters indicate significant changes $(p<0.05)$. Columns annotated by the same letter are not significantly different $(p>0.05)$. by the Environmental Quality Standard for Soils, GB 15618-1995. The contents of the other heavy metals (As, $\mathrm{Cr}, \mathrm{Pb}, \mathrm{Cu}$, and $\mathrm{Zn}$ ) were below the national standard. This indicates that the apple orchard soil was contaminated with $\mathrm{Cd}$ and $\mathrm{Hg}$. $\mathrm{As}, \mathrm{Cd}$, and $\mathrm{Hg}$ concentrations in the apples exceed the food pollutant limits specified by national food safety standards, especially for $\mathrm{Hg}$, which was 25 times above the allowable limit. Consequently, finding and removing the contamination source merits serious attention. From highest to lowest, the order of migration rates
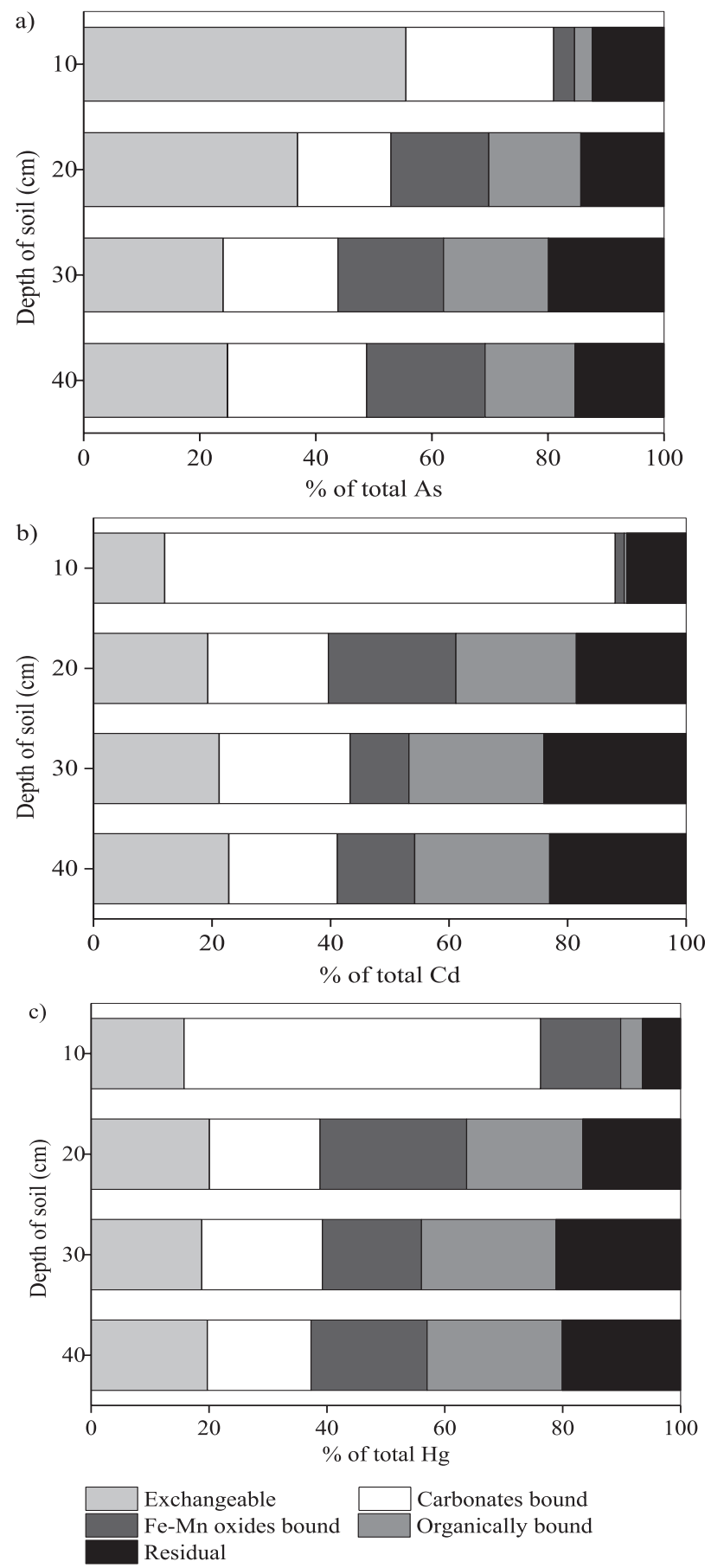

Fig. 5. Speciation of a) As, b) $\mathrm{Cd}$, and c) $\mathrm{Hg}$ at different soil depths. 
Table 2. Heavy metal contents $(\mathrm{mg} / \mathrm{kg})$ of apple orchard soil and fruit.

\begin{tabular}{|c|c|c|c|c|c|c|c|}
\hline Parameter & $\mathrm{As}$ & $\mathrm{Cd}$ & $\mathrm{Hg}$ & $\mathrm{Cr}$ & $\mathrm{Pb}$ & $\mathrm{Cu}$ & $\mathrm{Zn}$ \\
\hline Apple orchard soil $^{\mathrm{a}}$ & $10 \pm 1$ & $6.15 \pm 0.64$ & $5.12 \pm 0.39$ & $23 \pm 3$ & 0 & $12 \pm 3$ & $18 \pm 4$ \\
\hline Standard for soil $^{\mathrm{b}}$ & $\leq 40$ & $\leq 0.30$ & $\leq 0.30$ & $\leq 150$ & $\leq 250$ & $\leq 150$ & $\leq 200$ \\
\hline Apple & $1.1 \pm 0.1$ & $0.07 \pm 0.01$ & $0.25 \pm 0.05$ & $0.3 \pm 0.0$ & $\mathrm{ND}$ & $4 \pm 0$ & $2 \pm 0$ \\
\hline Food contamination limit $^{\mathrm{c}}$ & $\leq 0.5$ & $\leq 0.05$ & $\leq 0.01$ & $\leq 0.5$ & $\leq 1$ & $\leq 10$ & $\leq 5$ \\
\hline Migration rate $^{\mathrm{d}}$ & 0.106 & 0.011 & 0.049 & 0.012 & 0 & 0.309 & 0.090 \\
\hline
\end{tabular}

a Soil depth: $\sim 10-40 \mathrm{~cm}$.

${ }^{\mathrm{b}}$ Chinese Environmental Quality Standard for soil (GB 15618-1995)

c National standard for food safety - contaminant limits (GB 2762-2012)

${ }^{\mathrm{d}}$ Migration rate $=$ heavy metal content in fruit $/$ heavy metal content in soil .

of heavy metals from the soil to the apple fruit was found to be $\mathrm{Cu}>\mathrm{As}>\mathrm{Zn}>\mathrm{Hg}>\mathrm{Cr}>\mathrm{Cd}>$ and $\mathrm{Pb}$. The high migration rate of $\mathrm{As}$ in apple fruit is the main reason for As exceeding the standard. In addition to the use of chicken manure compost, whose heavy metal contents exceeded the standard, the physicochemical properties of the orchard soil, the use of pesticides and chemical fertilizers, and atmospheric deposition all contribute to soil and fruit heavy metal contents that exceed national standards [27-29].

\section{Conclusions}

This investigation of heavy metal content and speciation within the chicken manure-compost-soilapple system showed that the contamination levels of As, Cd, and $\mathrm{Hg}$ remained high throughout the system, whereas levels of other heavy metals remained fairly low. This indicates that heavy metals contained in chicken manure can migrate and accumulate in soil and crops, thus posing a significant threat to ecosystem safety and human health.

\section{Acknowledgements}

This work was financially supported by the Innovation Team Project for Modern Agricultural Industrious Technology System of Shandong Province (SDAIT-11-10), Key Research and Development project of Shandong Province (2019GSF107094), Major Science and Technology Innovation Project of Shandong Province (2017GGH5129), Natural Science Foundation of Shandong Province (ZR2016YL031), Project of Shandong Province Higher Educational Science and Technology Program (No. J18KB077), and Yantai Science and Technology Project (No. 2017NC049).

\section{Conflict of Interest}

The authors declare no conflict of interest.

\section{References}

1. ZHANG F., LI Y., YANG M., LI W. Content of Heavy Metals in Animal Feeds and Manures from Farms of Different Scales in Northeast China. Int J Env Res Public Health, 9 (8), 2658, 2012.

2. YANAN W., QINGQING H., QI W., YAO Y., DECHUN S., YUHUI Q., HUAFEN L. Accumulation and bioavailability of heavy metals in an acid soil and their uptake by paddy rice under continuous application of chicken and swine manure. Journal of Hazardous Materials, 384, 121293, 2020.

3. FAN Y., LI H., XUE Z., ZHANG Q., CHENG F. Accumulation characteristics and potential risk of heavy metals in soil-vegetable system under greenhouse cultivation condition in Northern China. Ecol Eng, 102 (Supplement C), 367, 2017.

4. ONAKPA M.M., NJAN A.A., KALU O.C. A Review of Heavy Metal Contamination of Food Crops in Nigeria. Ann Glob Health, 84 (3), 488, 2018.

5. TESSIER A., CAMPBELL P.G.C., BISSON M. Sequential extraction procedure for the speciation of particulate trace metals. Analytical Chemistry, 51 (7), 844, 1979.

6. RENFEI L., WENBING T., GUOAN W., XINYU Z., QIULING D., HANXIA Y., BEIDOU X. Nitrogen addition promotes the transformation of heavy metal speciation from bioavailable to organic bound by increasing the turnover time of organic matter: An analysis on soil aggregate level. Environmental Pollution, 255 (1), 113170, 2019.

7. ANA D.S., INMACULADA V., JOSE R.Q., ANTONIO V., ANTONIO L.L., CONCEPCIÓN G. Carbonate, organic and clay fractions determine metal bioavailability in periurban calcareous agricultural soils in the Mediterranean area. Geoderma, 221, 103, 2014.

8. KOMAREK M., TLUSTOS P., SZAKOVA J., CHRASTNÝ V., BALIK J. The role of Fe- and Mnoxides during EDTA-enhanced phytoextraction of heavy metals. Plant Soil and Environment, 53 (5), 216, 2018.

9. KWON S., JANG Y., KIM K., JUNG G., KIM M., HWANG H., CHAE M., HONG S., SO K., YUN S., KIM $\mathrm{K}$. Heavy metal chemistry in soils received long-term application of organic wastes. Journal of Agricultural Chemistry and Environment, 1 (1), 1, 2012.

10. NENGMIN Z., QIANG L., XUJING G., HUI Z., YU D. Sequential extraction of anaerobic digestate sludge for the determination of partitioning of heavy metals. Ecotoxicology and Environmental Safety, 102, 18, 2014. 
11. DONG B., LIU X., DAI L., DAI X. Changes of heavy metal speciation during high-solid anaerobic digestion of sewage sludge. Bioresour Technol, 131 (Supplement C), $152,2013$.

12. LV B., XING M., YANG J. Speciation and transformation of heavy metals during vermicomposting of animal manure. Bioresour Technol, 209 (Supplement C), 397, 2016.

13. LIU L., CHEN H., CAI P., LIANG W., HUANG Q. Immobilization and phytotoxicity of $\mathrm{Cd}$ in contaminated soil amended with chicken manure compost. J Hazard Mater, 163 (2), 563, 2009.

14. WANG Q., LIU J., CHENG S. Heavy metals in apple orchard soils and fruits and their health risks in Liaodong Peninsula, Northeast China. Environ Monit Assess, 187 (1), 4178, 2014.

15. CAI L., XU Z., BAO P., HE M., DOU L., CHEN L., ZHOU Y., ZHU Y. Multivariate and geostatistical analyses of the spatial distribution and source of arsenic and heavy metals in the agricultural soils in Shunde, Southeast China. Journal of Geochemical Exploration, 148, 189, 2015.

16. NIU L., YANG F., XU C., YANG H., LIU W. Status of metal accumulation in farmland soils across China: From distribution to risk assessment. Environ Pollut, 176 (Supplement C), 55, 2013.

17. WANG Q.Y., ZHOU D.M., CANG L. Microbial and enzyme properties of apple orchard soil as affected by long-term application of copper fungicide. Soil Biol Biochem, 41 (7), 1504, 2009.

18. AMANDA V.E., LEE B. Antibiotic Residues in Animal Waste: Occurrence and Degradation in Conventional Agricultural Waste Management Practices. Curr Pollution Rep, 2, 135, 2016.

19. BURGER J., GOCHFELD M. Heavy metals in commercial fish in New Jersey. Environ Res, 99 (3), 403, 2005.

20. WU S., SHEN Z., YANG C., ZHOU Y., LI X., ZENG G., AI S., HE H. Effects of $\mathrm{C} / \mathrm{N}$ ratio and bulking agent on speciation of $\mathrm{Zn}$ and $\mathrm{Cu}$ and enzymatic activity during pig manure composting. International Biodeterioration \& Biodegradation, 119, 429, 2017.

21. ZHU W., YAO W., ZHANG Z., WU Y. Heavy metal behavior and dissolved organic matter (DOM) characterization of vermicomposted pig manure amended with rice straw. Environmental Science and Pollution Research, 21 (22), 12684, 2014.

22. HE X., ZHANG Y., SHEN M., ZENG G., ZHOU M., Li M. Effect of vermicomposting on concentration and speciation of heavy metals in sewage sludge with additive materials. Bioresour Technol, 218 (Supplement C), 867, 2016.

23. GUSTAVO B., LUCAS B., VÍTOR G.A., JUCINEI J.C., GEORGE W.B.M., MATHEUS A.S., CLEDIMAR R.L., ARCANGELO L., PAULO B.F., DJALMA E.S., RAFAEL C. Copper and zinc fractions in the profile of an Inceptisol cultivated with apple in southern Brazil. Soil and Plant Nutrition, 77 (2), 333, 2018.

24. OBRIST D., JOHNSON D.W., LINDBERG S.E., LUO Y., HARARUK O., BRACHO, R., BATTLES J.J., DAIL D.B., EDMONDS R.L., MONSON R.K., OLLINGER S.V., PALLARDY S.G., PREGITZER K.S., TODD D.E. Mercury Distribution Across 14 U.S. Forests. Part I: Spatial Patterns of Concentrations in Biomass, Litter, and Soils. Environ Sci Technol, 45(9), 3974, 2011.

25. MBUVI H. Speciation of Cadmium and Lead in Garage Soils from Ngara- Nairobi and Their Levels in Nearby Vegetables and Water. International Journal of Physical and Social Sciences, 4, 89, 2014.

26. YUAN X., HUANG H., ZENG G., LI H., WANG J., ZHOU C., ZHU H., PEI X., LIU Z., LIU Z. Total concentrations and chemical speciation of heavy metals in liquefaction residues of sewage sludge. Bioresour Technol, 102 (5), 4104, 2011.

27. RAI P.K., LEE S.S., ZHANG M., TSANG Y.F., KIM K.H. Heavy metals in food crops: Health risks, fate, mechanisms, and management. Environment International, 125, 365, 2019.

28. TÓTH G., HERMANN T., SILVA M.R.D., Montanarella L. Heavy metals in agricultural soils of the European Union with implications for food safety. Environment International, 88, 299, 2016.

29. HAILONG L., JUN Z., MIN L., YUANMEI H., XIAOLI L., JING Z. Study of the bioavailability of heavy metals from atmospheric deposition on the soil-pakchoi (Brassica chinensis L.) system. Journal of Hazardous Materials, 362, 9, 2019. 